\title{
The Importance of Environmental Safety Evaluation of Beaches Changchun Zhou*
}

College of Geography and Tourism, Qufu Normal University, Rizhao 276826, Shandong, China

*Corresponding author: Changchun Zhou, College of Geography and Tourism, Qufu Normal University, 80 Yantai Road, Rizhao 276826 , Shandong, China, Tel: +86 633 3980710, Fax: +86 633 3980716; E-mail: zhouchchun@163.com

Received date: January 8, 2016; Accepted date: January 19, 2016; Published date: January 26, 2016

Copyright: (c) 2016 Zhou C. This is an open-access article distributed under the terms of the Creative Commons Attribution License, which permits unrestricted use, distribution and reproduction in any medium, provided the original author and source are credited.

\begin{abstract}
Tourism is the largest industry in the world and beaches are the major factor in this tourism market. However, in the activities of beaches' tourism, some environmental indexes of beaches have significant effects on tourists' experience, physical health, and even life safety. Based on the aim of providing safe and healthy services for tourists, some beach evaluation or rating systems in some European countries and the United States are described and advance in research of environmental safety evaluation of beaches in China is discussed, and the main problems and practical challenges in beach management are pointed out, which is exactly what I am working on.
\end{abstract}

Keywords: Beach tourism; Environmental safety; Evaluation system

\section{Introduction}

$60 \%$ of the world's population lives in areas within a distance of a $100 \mathrm{~km}$ from the sea at the end of the last century [1]. Coastal tourism is the largest market segment of global tourism [2-4]. At California beaches, each year nearly 150-400 million visits generated billions of dollars expenditures [5]. On the Miami Beach, more than 2 million visitors per annum brought over $\$ 130$ million federal tax revenue [6]. At the Australian Gold Coast, 65, 000 to 120, 000 surfers spent AU\$ 126-233 million per year [7]. Therefore, beach plays a significant role in tourism.

As a kind of tourism resource, beach can be viewed as an aggregate that is composed of the following environmental factors: sediment, topography, seawater, weather and climate, hydrology, human management, etc. In the activities of coastal tourism, some indexes of the coastal environment and management (such as seawater quality, hydrological and meteorological condition, sediment, safety education, danger warning, etc.) can have remarkable effects on tourists' experience, physical health, and even life safety. For example, it is estimated by a recent research that polluted coastal waters generate more than 120 million gastroenteritis (GI) episodes and 50 million Acute Respiratory Disease (ARD) episodes every year globally, causing $\$ 12$ billion per year in public health costs [8]. For another instance, drowning is a major public health problem. Average 82 people suffered fatal drowning annually on Australia beaches [9] and the primary cause of death was rip currents [10]. Consequently, it is very important to evaluate environmental safety condition of beaches through an evaluation index system in order to guarantee tourism safety of beaches. Our objective is intended to help policy makers and beach managers understand and potentially improve the environmental safety condition of beaches, and help beachgoers better choose beaches and tourism activities which are fit for them.

There are many different beach rating systems in the world [7]. The Blue Flag maybe be the most well known of European award schemes and is run by the Foundation for Environmental Education (FEE), based in Denmark [11]. The Quality Coast Award introduced in 2007 by Environmental Campaigns which is an organization based in Wigan, UK. The Good Beach Guide is a book that is published by the Marine Conservation Society (MSC), a Non Governmental Organization (NGO) based at Ross on the Wales/England Border, UK. This guide consists of two main sections. The first section is water quality criteria and the second one provides a range of information such as safety, facilities, wildlife, seaside activities, etc. The Green Sea Initiative is supported by 30 public and private organizations such as local authorities, the private sector, statutory agencies, environmental and voluntary organizations. It is a major national project dedicated to the protection and improvement of coastal waters and beaches around Wales, UK and administered by Keep Wales Tidy. The Clean Beaches Council, a US Nonprofit Organization, launched 'Blue Wave Campaign' [12], and so on.

These evaluation or rating systems pay close attention to the assessment of safety factors and thus play a key role in maintaining and guaranteeing the safety of beaches. Based on 821 questionnaires' survey in four bathing beaches of Wales from 1995 to $1996,40 \%$ of tourists asserted that these rating activities had influence on their choices of bathing beaches.

Since 2003, water quality, meteorology and hydrology condition have been monitored and predicted in the swimming seasons of the 23 primary bathing beaches of China. However, up to date, there is no corresponding evaluation or rating system of beaches at the national level in China. Though some scholars have done some work [13-24], the majority of their work mainly focuses on water quality evaluation. Wang [25] established an evaluation index system of environmental safety of beaches. Although his evaluation system is comparatively comprehensive, certain natural and management factors, such as tide, red tide, storm surge, tourist density, facility condition, personnel allocation, etc, are seldom included.

\section{Conclusion}

Therefore, at present, from the perspectives of providing health and safety services for beachgoers, the inclusion of these important natural and management factors in an evaluation index system of beaches is necessary to evaluate and classify beaches in China. And that's exactly what I am working on. 
Citation: Zhou C (2016) The Importance of Environmental Safety Evaluation of Beaches. J Coast Zone Manag 19: 416. doi: $10.4172 / 2473-3350.1000416$

Page 2 of 2

\section{References}

1. Von Bodungen B, Turner RK (2001) Science and integrated coastal management. An introduction. Dahlem University Press, Berlin.

2. Hall CM (2001) Trends in ocean and coastal tourism: the end of the last frontier? Ocean and coastal management 44: 601-618.

3. Honey M, Krantz D (2007) Global trends in coastal tourism. Center on Ecotourism and Sustainable Development.

4. United Nations Environment Program (UNEP) (2009) Sustainable Coastal Tourism. An integrated planning and management approach.

5. Given S, Pendleton L, Boehm AB (2006) Regional public health cost estimates of contaminated coastal waters: a case study of gastroenteritis at Southern California Beaches. Environmental Science and Technology 40: 4851-4858.

6. Houston JR (2002) The economic value of beaches: A 2002 Update. Shore and Beach 70: 9-12.

7. Williams A, and Micallef A (2009) Beach management: principles \& practice. Earthscan, London.

8. Shuval H (2003) Estimating the global burden of thalassogenic diseases: human infectious diseases caused by wastewater pollution of the marine environment. Journal of Water Health 1: 53-64.

9. Surf Life Saving Australia (2008) 2008 National Coastal Safety Report. Surf Life Saving Australia, Sydney.

10. Sherker S, Williamson A, Hatfield J, Brander R, Hayen A (2010) Beachgoer's beliefs and behaviours in relation to beach flags and rip currents. Accident Analysis and Prevention 42: 1785-1804.

11. FEE (2013) Official web page for the Foundation for environmental education.

12. Mcleod WL, Evans C (2005) The blue wave campaign-creating and ecoethic. Proceedings of the 14th biennial coastal zone conference, New Orleans, Louisiana.

13. Nelson C, Williams AT, Liu HB (1999) Award schemes and beach selection by tourists-a Welsh (UK) perspective. Coast Engineering 18: 156-168.

14. Ma CY (1997) Analysis and countermeasures of the status quality of the seawater of the sea baths areas along Qinhuangdao coast. Marine Environmental Science 16: 67-71.
15. Zheng JY, Qie ZY, Li XL (1998) The environmental quality assessment on the bathing beaches in south seashore of Qingdao City. Marine Environmental Science 17: 66-72.

16. Yang DN, Yuan DX, Xu PX, Deng YZ (1999) Monitoring and preservation of coastal bathing water quality of Xiamen in swimming season. Environmental Science 20: 75-78.

17. Chen CH, Wang L, Wang DR (1996) Water quality condition and analysis of its influencing mechanism of Xiuying bathing beach in Haikou Bay. Acta Oceanologica Sinica 18: 45-52.

18. Han QQ, Zheng WH, Lian WL, Qiu JR, Weng F, Zhou M (2003) Investigation and analysis of water quality condition in Gulangyu bathing beach, Xiamen. Chinese Journal of Convalescent Medicine 12: 321-322.

19. Gu JQ, Liu GB, Zhang JM (1996) Effect of deposition parameters of development mode In Hebi beach. Geography and Territorial Research 12: 21-25.

20. Zhao NX, Yang DY (1996) Evaluation in physiological environment of a seaside tourism \& vacation district. Marine Science 6: 66-68.

21. Lv Y, Zhang WD, Gao Y, Ning SX, Yang B (2011) Preliminary study on responses of marine nematode community to crude oil contamination in intertidal zone of Bathing Beach, Dalian. Marine Pollution Bulletin 62: 2700-2706.

22. Fan JF, Ming HX, Wu LJ, Liang YB, Li X (2011) Investigation of fecal coliform and typical enteric virus in representative beaches of China. Marine Science Bulletin 13: 72-81.

23. Zhang WW, Wang JY, Fan JF, Gao DL, Ju HY (2012) Effects of rainfall on microbial water quality on Qingdao No. 1 Bathing Beach, China. Marine Science Bulletin 66: 185-190.

24. Thoe W, Wong SHC, Choi KW, Lee JHW (2012) Daily prediction of marine beach water quality in Hong Kong. Journal of Hydroenvironment Research 6: 164-180.

25. Wang XQ (2006) Research on evaluating environment safety of bathing beaches. Doctoral degree dissertation of China University of Geosciences: 158. 